\title{
PERAN PEREMPUAN DALAM PEMBERDAYAAN EKONOMI SYARIAH
}

\author{
Alamul Huda \\ Fakultas Syariah Universitas Islam Negeri Maulana Malik Ibrahim Malang \\ Email:alamulhuda09@gmail.com
}

\begin{abstract}
Abstrak
Women movement in contemporary context is a ovement which has value, meaning and its own's potential. The movement covers several factors in society, and one of them is women's effort and strenght in improving living standart of the society. Furthermore, actualization of this empowerment is in forms of building and developing women cooperative institution as a medium for increaing economics' welfare of socety. The succes of that cooperative institution gives proof and important meaning of the influence and the present of women in the middle of society as well as deconsts doubt stigma towards women's role and their strenght. Then, phenomenollogy, the existence of women cooperative institution is the actualization of role and economics empowerment of society by women is the proof of women's strenght in social realm and society.

Gerakan perempuan dalam konteks kekinian adalah gerakan yang memiliki nilai, arti dan potensi tersendiri. Hal ini meliputi sekian banyak factor di dalam masyarakat, dan salah satu diantaranya adalah daya ikhtiyar dan upaya kekuatan perempuan dalam meningkatkan taraf hidup masyarakat. Selanjutnya, aktualisasi pemberdayaan ini adalah dalam bentuk pendirian dan pengembangan koperasi wanita sebagai sarana meningkatkan kesejahteraan ekonomi masyarakat. Kesuksesan yang ditunjukkan oleh koperasi wanita ini memberi bukti dan arti penting, makna pengaruh dan kehadiran perempuan di tengah masyarakat, sekaligus mendobrak stigma keraguan akan peran dan kekuatan perempuan. Selanjutnya, secara fenomenologis, eksistensi koperasi wanita adalah aktualisasi peran dan pemberdayaan ekonomi masyarakat oleh perempuan merupakan bukti akan kekuatan perempuan dalam ranah social dan masyarakat.
\end{abstract}

Kata Kunci: Perempuan, Pemberdayaan, Ekonomi

Keberadaan koperasi yang kita kenal hari ini, memiliki peranan yang amat berarti dalam sejarah perkembangan perekonomian di Indonesia. beberapa hasil studi dan kajian lapangan atas kasus koperasi menunjukkan satu realitas bahwa eksistensi koperasi tidak saja memberi keuntungan (profit) pada para anggotanya tetapi amat berperan dalam menyerap pegawai atau tenaga kerja di mana koperasi itu tumbuh dan berkembang.
Disamping hal tersebut, peran nyata koperasi, terbukti telah memberikan kesejahteraan yang jauh lebih baik untuk masyarakat, dimana koperasi tersebut berada. Sedang dalam ranah pengentasan kemiskinan dan upaya peningkatan kesejahteraan masyarakat, peranan koperasi bisa dikatakan sebagai tulang punggung (backbone) yang penting bagi kesejahteraan keluarga para anggota koperasi. Selanjutnya di sisi lain, dalam wadah koperasi wanita, dimana 
adanya peranan wanita dapat teraktualisasikan, sekaligus -hal itu- menjadi dibutuhkan, dan secara fakta, keberadaan koperasi dapat menjadi salah satu wadah aktualiasasi yang strategis disamping juga dapat amat efisien dijadikan sebagai media kreatifitas wanita dalam pengembangan ekonomi kerakyatan.

\section{Fenomena Koperasi Wanita}

Era reformasi pada bulan Mei 1998 di Indonesia telah memberi angin perubahan terhadap berbagai gerakan kemasyarakatan, munculnya aspirasi rakyat dengan adanya berbagai ormas serta berbagai forum maupun kelompok yang memiliki wajah yang sangat berbeda, terutama dari sisi pendekatan terhadap suara rakyat dan gerakan sosial politik pada saat pemerintahan rezim orde baru yang cenderung bersifat sentralistik dan penuh tekanan. Fenomena itu menimpa gerakan masyarakat kaum perempuan saat itu yang cenderung monoton dan kurang menggali kreatifitas serta potensi kaum perempuan, walaupun pada saat itu sudah terbentuk organisasi formal perempuan seperti Dharma Wanita dengan program utamanya yaitu PKK. ${ }^{1}$

Keberadaan organisasi Dharma Wanita melalui program PKK memiliki misi mulia dengan tujuan untuk mendidik dan mensejahterakan keluarga, dengan potensi prosentase jumlah perempuan Indonesia dari keseluruhan data statistik penduduk adalah sekitar $50.3 \%$, bahkan ada yang menyebut dalam kisaran jumlah sekitar $53 \% .^{2}$ Dengan potensi yang besar, namun di rasa masih kurang optimal implementasinya

${ }^{1}$ Gerakan PKK atau Pendidikan Kesejahteraan Keluarga adalah gerakan pembangunan masyarakat yang tumbuh dari bawah dengan perempuan sebagai motor penggeraknya untuk membangun keluarga sebagai unit atau kelompok terkecil dalam masyarakat guna menumbuhkan, menghimpun, mengarahkan, dan membina keluarga guna mewujudkan keluarga sejahtera. Lihat: http://www.slideshare.net/ imraanmuslim/bab-iipkkpemberdayaan-ekonomi. (di akses 24 Juli 2012)

${ }^{2}$ http://eljannahraheem.blogspot.com/2008/12/ peranan-wanita-dalam-masyarakat.html (diakses tanggal 19 oktober 2012), lihat: http://batikyogya. word press.com/2008/08/21/peranan-perempuandalam-pembangunan-bangsa. (diakses 17 0ktober 2012) dalam pembangunan, dikarenakan masih kentalnya uniformitas, sifat tunggal yang rigid serta "pemujaan" yang lebay serta berlebihan terhadap formalisasi kekuasaan orde baru yang cenderung "mengekang" kreativitas dan gerakan perempuan, sehingga walau sudah berdiri organisasi wanita tapi pada hakikatnya gerakannya terbatas.

Pada era reformasi yang di tandai dengan tumbanganya rezim orde baru, gerakan organisasi perempuan seakan telah menemukan ruang untuk mengekspresikan kebebasan dan kreatifitasnya, terutama melalui gerakan pemberdayaan masyarakat. Orde reformasi yang terjadi di Indonesia pasca tumbangnya pemerintahan Presiden Suharto pada tahun 1998, turut mendorong adanya peran serta perempuan di segala lini kehidupan berbangsa dan bermasyarakat, tidak terkecuali dalam upaya program penguatan ekonomi, dimana gerakan perempuan menemukan bentuknya, mereka dengan optimism yang tinggi serta sentuhan khas perempuan yang penuh inovasi dengan membangun koperasi perempuan, yang tujuannnya adalah untuk meningkatkan taraf hidup masyarakat.

Kekuatan perempuan untuk mendirikan KOPWAN (Koperasi Wanita) adalah sebuah keinginan luhur dalam upaya mensejahterakan komunitas masyarakat secara riil dan kongkrit. Partisipasi seperti itu adalah kiprah nyata perempuan dalam membangun masyarakat madani (civil society) melalui program peningkatan taraf hidup masyarakat. Tidaklah dapat di pungkiri, bahwa peran besar perempuan yang ikut andil dalam sejarah perjuangan bangsa Indonesia, rekam jejak (track record) sejarah tersebut dapat menjadi potensi luar biasa dalam mengantarkan pada cita-cita masyarakat madani.

Disisi yang lain, tentunya kita tidak bisa melupakan peran besar perempuan dalam penguatan ekonomi, khususnya upaya pengembangan perkoperasian di Indonesia. Dikatakan demikian karena ternyata koperasi yang dijalankan oleh perempuan memiliki nilai dan perkembangan yang cukup positif. 
Perkembangan koperasi di Indonesia, khususnya koperasi yang dikelola wanita, ternyata cukup menarik perhatian dari pemerintah maupun para pembinanya, karena koperasi-koperasi tersebut menunjukkan perkembangan kinerja yang baik. ${ }^{3}$

Dilihat dari sisi organisasi maupun usaha yang di kembangkannya, terbukti ada satu pertanyaan yang menggelitik kita, bahwa koperasi wanita yang berkembang cendrung konsisten dalam menjalankan prinsip-prinsip dan nilai-nilai koperasi. Kecendrungan ini disebabkan oleh beberapa hal yang intrinsik atau berpadu dengan kondisi perempuan yang memiliki kelebihan dari laki-laki. Dalam konteks kasus tersebut, terlihat bahwa perempuan memiliki keunggulan khususnya dalam pengelolaan koperasi. Keunggulan tersebut mewujud dalam keuletan, kejujuran dan ketelitian dalam menangani berbagai dinamika persoalan koperasi perempuan. ${ }^{4}$

Koperasi yang sudah dikenal sebagai sokoguru perekonomian nasional, adalah koperasi yang didirikan dan dimotori oleh kaum perempuan. Koperasi tersebut dikenal dengan koperasi wanita (kopwan) yang menjadi roda penggerak ekonomi masyarakat. Misalnya Kopwan AnNisa yang berada di Desa Klenang Kidul, Kecamatan Banyuanyar, Kabupaten Probolinggo, merupakan salah satu contoh bangaimana peran dan kekuatan perempuan dalam membangun masyarakatnya. Dengan langkah perlahan namun pasti, koperasi perempuan yang di beri nama "An-Nisa" ini terus merangkak berkembang. Biasanya koperasi didirikan atas dasar adanya kebutuhan, tujuan dan kepentingan yang sama, begitu pula berdirinya koperasi wanita "An-Nisa" yang merupakan koperasi yang didirikan karena kebutuhan dan kepentingan yang sama yaitu dalam upaya menambah penghasilan, memberdayakan dan meningkatkan perekonomian keluarga dan masyarakat serta anggota koperasi.

Berangkat dari kepentingan bersama, roda

\footnotetext{
3 http://www.smecda.com/kajian/files/ hslkajian/wanita/2_Pendahuluan.pdf.

${ }_{4}$ http://www.smecda.com/kajian/files/ hslkajian/wanita/2_Pendahuluan.pdf.
}

koperasi yang sejak awal bergerak melalui penawaran produk simpan pinjam tanpa bunga. Keuntungannya dari modal bersifat pinjaman lunak (qord al-hasan), sehingga sistem yang di gunakan dalam simpan pinjam ini bersifat adil dan islami (bersifat syar'i), artinya bahwa koperasi muslimat "An-Nisa" tidak memberatkan terhadap anggotanya, akan tetapi justru sebaliknya untuk meningkatkan taraf perekonomian para anggotanya. Anggota koperasi yang rata-rata adalah kaum dhuafa' akan mendapatkan pinjaman dengan sistem qord al-hasan sehingga cukup mengembalikan pokok saja. Pada dasarnya, sistim qord al-hasan ini lebih cenderung bersifat sosial non profit an sich. ${ }^{5}$ Gayungpun bersambut, upaya tidak bertepuk sebelah tangan, dan masyarakat terus mendaftar sebagai anggota koperasi, sehingga koperasi wanita itupun makin diminati masyarakat.

Dalam keseharian, kita sering mendengar kata pemberdayaan, baik dalam posisi sebagai tuntutan kewajiban bagi akademisi ataupun pelaksanaannya di tengah-tengah masyarakat. Selanjutnya bila ditelisik secara pendekatan makna, kata "pemberdayaan" sendiri adalah kekuatan yang berasal dari dalam yang diperkuat oleh unsur-unsur dari luar, termasuk di dalamnya adalah membangun daya, mendorong, memberikan motivasi, dan membangkitkan kesadaran akan potensi yang di milikinya serta berusaha untuk mengembangkannya. ${ }^{6}$

\section{Produktifitas Menuju Kemandirian}

Bila dilacak dalam kamus Oxford English Minidictionary memberikan artibagi pemberdayaan dengan kata empower dan mengartikannya dengan give strenght and confidence to dua kata ini memiliki arti; kata pertama memberikan daya kekuatan kepada pihak lain, dan kekuasaan pada otoritas lain, sedangkan pada kata kedua, adalah menumbuhkan rasa percaya diri karena adanya kemandirian dalam sebuah usaha yang

\footnotetext{
$5 \quad$ Tentang pinjaman dengan sistim qordhul hasan lebih bersifat social, lihat: http://www. bprsyariah.com/ (diakses tanggal 9 Oktober 2012)

Ibid. h. 44 .
} 


\section{di lakukannya. ${ }^{7}$}

Peran serta perempuan dalam peningkatan taraf hidup masyarakat, apabila kita telaah secara lebih seksama merupakan pemberdayaan masyarakat yang maknanya dapat disamakan dengan perolehan dan akses terhadap sumberdaya untuk mencari nafkah. ${ }^{8}$ Lihatlah sejenak bahwa perempuan telah memberikan suatu andil terhadap masyarakatnya, disamping sebagai ibu rumah tangga, mereka juga mencoba peduli pada komunitas dimana mereka tinggal dan berdomisili. Selanjutnya Pearse dan Stiefel menyatakan, bahwa menghormati kebhinekaan, kekhasan lokal, dekonsentrasi kekuatan dan peningkatan kemandirian merupakan bentukbentuk pemberdayaan partisipatif. ${ }^{9}$

Sikap "penolakan" kaum perempuan terhadap pendirian sebagian kaum konservatif dan penyematan nilai budaya di tengah masyarakat, serta distorsi perempuan atas nama agama, bahwa peran perempuan hanya sebagai ibu rumah tangga, mendidik anak dan melayani suami, tidak boleh terjun di dunia politik apalagi menjadi hakim dan kepala pemerintahan, adalah karena adanya suatu pandangan bahwa hal itu merupakan tugas kaum laki-laki. ${ }^{10}$

Kekhasan lokal menjadi modal kemandirian karena dengannya akan tercipta keberagaman, tingkat diversifikasi dan warna dalam masyarakat. Berangkat dari aspek ini, sebagai bagian dari komunitas masyarakat, sudah barang tentu bila perempuan dapat berperan dan sekaligus menjadi motor penggerakuntuk memberdayakan dirinya, menggali segenap potensi dan sekaligus memberi pelajaran kepada masyarakat untuk mengembangkannya. ${ }^{11}$

\footnotetext{
Georgia Hole and Sara Hawker, Oxford Mini Dictionary,(NewYork: Oxford University Press, 2004), p.181.

${ }^{8}$ Masykuri Bakri, Dekonstruksi Jalan Terjal Pembangunan Negara Dunia Ketiga (PerspektifPendidikan, Pemberdayaan dan Pelayanan Publik), (Surabaya: Visipress, 2011), h. 45.

9Ibid.,h. 45.

${ }^{10} \mathrm{http}$ ://eljannahraheem.blogspot.com/2008/12/ peranan-wanita-dalam-masyarakat.html (diakses Tanggal 19 Oktober 2012)

${ }_{11}$ Pemberdayaan oleh perempuan dapat di pandang sebagai usaha mendorong terjadinya suatu proses perubahan sosial yang memungkinkan masyarakat pinggiran yang tidak berdaya untuk dapat
}

Pemberdayaan adalah konteks pengupayaan terhadap suatu masyarakat sehingga berdaya, memiliki kesadaran bahwa kehadiran individuindividu di dalamnya merupakan memiliki potensi dan kemampuan lebih dari yang dirasakan. Pemberdayaan adalah suatu kondisi atau keadaan yang mendudukung adanya kekuatan atau kemampuan yang dimiliki masyarakat sehingga mereka dapat mengaktualisasikan jati diri, hasrat dan martabatnya secara maksimal untuk bertahan dan mengembangkan diri secara mandiri. ${ }^{12}$ Konsep pemberdayaan yang dilakukan oleh sekelompok perempuan terbilang unik dan inovatif, karena meskipun dipandang sebelah mata, mereka pantang menyerah untuk memberdayakan diri.

\section{Potensi untuk Maju}

Muhammad Nabil Kadzim, dalam salah satu bukunya, yang berjudul: “Merengkuh Kesuksesan (Success is Yours), di sana terdapat terdapat satu sub bab yang membahas tentang berbagai sumber motivasi pribadi dan dorongan manusia untuk maju, yaitu: (a) Motivasi instingtif, (b) Motivasi diri, (c) Dorongan keunggulan, dan (d) Mewujudkan Identitas. ${ }^{13}$ Yang menarik disini adalah terdapat dalam pokok bahasan yang tertuang pada poin (b) dan (c) yang memiliki beberapa ulasan tentang keunggulan dan dorongan untuk lebih berprestasi, dan diantara motif paling kentara untuk membangun kesuksesan seseorang adalah bagaimana seseorang merealisasikan keinginan dan mengekspresikan (kebutuhan) dirinya dalam kehidupan. ${ }^{14}$

Berangkat dari sisi ini, tidaklah berlebihan bila dorongan (support) para perempuan untuk berani mengungkapkan jati dirinya dan berusaha semaksimal mungkin memompa potensinya serta menyatakan eksistensi identitasnya

memberikan pengaruh yang lebih besar di arena politik lokal ataupun nasional. Ibid. h. 46.

${ }^{12}$ Masykuri Bakri, Pemberdayaan Masyarakat; Pendekatan RRA dan PRA, (Surabaya: Visipress Media, 2011), h. 17-18.

${ }^{13}$ Nabil Muhammad Kadzim, Merengkuh Kesuksesan;Success is Yours, (Bogor: Hasyimi, 2008), h. 47-50.

${ }^{14}$ Ibid., h. 49-50. 
sehingga mereka berkumpul bersama, berkreasi, mendobraksegala keterbatasan untukmembentuk sebuah wadah guna menggapai kesejahteraan hidup yaitu dengan membentuk sebuah koperasi wanita untuk mencapai tujuan bersama yaitu kesejahteraan keluarga dan menolong masyarakat lewat sistem perekonomian yang saling menguntungkan.

Dorongan untuk sukses dengan jalan bekerja dan tidak berpangku tangan, juga menjadi salah satu alasan mengapa mereka mendirikan koperasi "An-Nisa". ${ }^{15}$ Dalam al-Qur'an Allah berfirman: "Dan Katakanlah (Muhammad):"Bekerjalah kamu, maka Allah dan Rasul-Nya serta orang-orang mu'min akan melihat pekerjaanmu itu" (QS. At-Taubah: 105). Bekerja dengan penuh semangat untuk berubah dan mandiri serta ingin bersama-sama sejahtera yang membuat para wanita ini membentuk sebuah wadah komunitas organisasi dengan agenda program ekonomi dengan visi dan misi mengangkat taraf hidup orang-orang di sekitarnya.

Motivasi diri yang begitu besar, dapat menciptakan sebuah wadah yang menggerakkan rasa percaya diri orang-orang di sekitarnya untuk lebih maju. Motivasi ini telah menimbulkan satu keinginan untuk belajar dan selalu menerima masukan yang berhubungan dengan hal ikhwal sekitar wawasan perkoperasian. Mengingat keterbatasan pendidikan, mereka terpacu untuk terus belajar mengikuti berbagai pelatihanpelatihan dan training perkoperasian baik yang diadakan oleh pihak pemerintah maupun organisasi lokal di prbolinggo. ${ }^{16}$ Upaya ini secara umum tentu merupakan bentuk usaha yang mulia, dimana dengan meningkatnya taraf hidup akan menjadi pemicu sekaligus

\footnotetext{
Dalam suatu wawancara dengan ketua koperasi wanita (KOPWAN) “An-Nisa" Rabu, 11 Juli 2012 dinyatakan bahwa: "Diantara motivasi yang mendorong kami adalah keinginan kuat untuk bekerja, membantu suami dan berbuat yang baik bagi keluarga adalah tujuan kami dalam mendirikan koperasi wanita (KOPWAN) "An-Nisa", dan saya pikir hal itu diperintahkan Allah Swt dalam al-Qur'an.

16 Menurut ketua KOPWAN "An-Nisa" bahwa pelatihan yang berasal dari pemerintah biasanya diadakan oleh Departemen Koperasi Kabupaten Probolinggo, yang diadakan sebulan sekali atau tiap semester baik di pendopo kabupaten ataupun di laksanakan di kecamatan Banyuanyar. Wawancara, Rabu, 11 Juli 2012.
}

simpul kestabilan kesejahteraan keluarga.

\section{Peningkatan Taraf Hidup Masyarakat}

Konteks pemberdayaan selalu mengacu pada kelompok masyarakat yang lemah, yaitu masyarakat yang berada pada kasta rendah akibat menjadi korban dinamika pembangunan. ${ }^{17}$ Peran perempuan menjadi penting kehadirannya dalam pemberdayaan ini, karena pada hakekatnya memberdayakan masyarakat adalah upaya untuk meningkatkan harkat dan martabat lapisan masyarakat yang dalam kondisi sekarang tidak mampu melepaskan diri dari jeratan perangkap kemiskinan dan keterbelakangan. Dari sisi terminologis, bila kita membedah kata pemberdayaan adalah sebuah upaya memampukan dan memandirikan masyarakat. ${ }^{18}$

Kata "memampukan" disini konotasinya adalah kenyataan bahwa kaum perempuan memberi ruang gerak dan sekaligus menyediakan bimbingan yang tulus dan terbuka kepada komunitas orang-orang yang berada disekitarnya. Bila dilihat dari segi tanggung jawab kemanusiaan baik secara individu dan sosial bahkan agama, keberadaan perempuan di tengah-tengah masyarakat mestilah menghadirkan warna tersendiri yang dinamis-konstruktif sebagaimana juga kaum laki-laki, dalam arti apapun kiprah perempuan dalam keluarga dan masyarakat tersebut. Dalam kontekstualisasnya, pemberdayaan (empowerment) adalah sebuah konsep yang lahir sebagai bagian dari perkembangan alam pikiran masyarakat dan kebudayaan. Pemberdayaan bukan dalam konteks mendominasi orang lain, melainkan menempatkan pemberdayaan sebagai suatu kecakapan untuk meningkatkan kemandirian (selfreliance) dan kekuatan dirinya (internal strength). ${ }^{19}$

Islam sebagai agama rahmatan lil alamin, merupakan agama yang berpihak pada perempuan. Islam tidak menghalangi wanita untuk memasuki berbagai profesi sesuai dengan keahliannya, seperti menjadi guru/

\footnotetext{
${ }^{17}$ Ibid., h. 47.

${ }^{18}$ Ibid., h. 47.

${ }^{19}$ Jurnal KARSA, Vol. 19. No.2. Tahun 2011, h.139.
} 
dosen, dokter, pengusaha, menteri, hakim dan lain-lain, bahkan bila ia mampu boleh menjadi perdana menteri atau kepala Negara, asal dalam tugasnya tetap memperhatikan hukum-hukum dan aturan-aturan yang telah ditetapkan oleh Islam. ${ }^{20}$ Bahkan dari sisi yang lain, kebenaran Islam begitu mempercayakan pada potensi besar perempuan dalam membangun masyarakat. Dalam tulisannya, Hasanatul Jannah menyatakan bahwa Islam sangat menekankan baik bagi lakilaki maupun perempuan untuk tumbuh dan berkembang sesuai dengan potensinya yang mengarah pada kebaikan bersama, sehingga melahirkan pola relasi yang harmonis, dinamis, toleran..$^{21}$

Peran perempuan di tengah masyarakat pada hakekatnya adalah membantu keluarga dalam mencapai sejahtera. Dengan kata lain, peran perempuan melalui pemberdayaan koperasi pada hakekatnya adalah untuk membantu suami dalam menafkahi keluarga atas dasar semangat saling tolong menolong dalam kebaikan. Dalam al-Qur'an, surat At-Taubah, ayat 71 Allah berfirman:

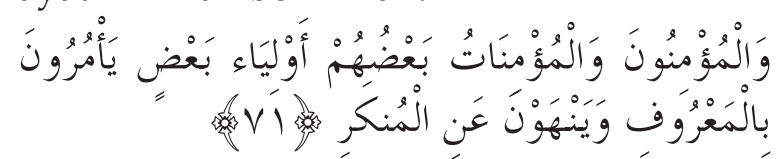

"Dan orang-orang yang beriman, laki-laki dań perempuan, sebagian mereka (adalah) penolong bagi sebahagian yang lain. Mereka menyuruh (mengerjakan) yang ma'ruf dan mencegah yang munkar." (QS. At-Taubah: 71)

Berdasarkan ayat tersebut, partisipasi perempuan sebagai istri bisa juga di lihat sebagai bentuk tanggung jawab terhadap fungsi sosial ekonomi seorang ibu rumah tangga di tengah kehidupan bermasyarakat. Sedangkan bila dicermati dari aspek religius, dengan mengutip tulisan Dr. Zaenul Mahmudi ${ }^{22}$ yang menyatakan bahwa ajaran yang bersifat qath'i yakni ajaran yang memiliki sifat prinsip dan universal khususnya yang berbicra tentang

\footnotetext{
${ }^{20} \mathrm{http}$ ://eljannahraheem.blogspot.com/2008/12/ peranan-wanita-dalam-masyarakat.html (diakses

${ }^{21}$ Jurnal KARSA, Vol. 19. No.2. Tahun 2011, h.139.

${ }^{22}$ Mahmudi, Zaenul. "Sosiologi Fikih Perempuan; Formulasi Dialektis Fikih Perempuan dengan Kondisi Sosial dalam Pandangan Imam Syafi'I", (Malang, UIN Press, 2009), h. 51-52.
}

kebebasan dan pertanggung jawaban individu sebagaimana yang termaktub dalam firman Allah Swt yang artinya: "Barang siapa yang mengerjakan kebaikan seberat biji dzarrahpun, niscaya dia akan melihat (balasan)nya. Dan barang siapa yang mengerjakan kejahatan seberat dzarrahpun, niscaya dia akan melihat (balasan) nya" (QS. Al-Zalzalah:7-8).

Bila kita cermati, minimal ada dua pesan utama dari ayat di atas, yaitu; (a) Bahwa apa yang dilakukan oleh seseorang di dalam hidupnya baik berupa perkerjaan yang (baik dan buruk) tidak akan lepas dari nilai yang nantinya akan dipertanggung jawabkan di depan amal timbangan (mizan) dan dihitung (hisab) di hadapan Allah Swt; (b) Bahwa amal manusia yang berupa amal sholeh tetap akan mendapatkan balasan yang setimpal atau bahkan berlipat ganda dari apa yang sudah di kerjakan, sehingga terkadang karena derajat keikhlasan pada saat seseorang beramal memiliki derajat yang tinggi, maka walau amal yang dilakukan itu terlihat dan terkesan remeh dimata manusia akan tetapi mulia di hadapan Allah swt, dan hal itu menyebabkan pemilik amal tadi masuk sorga.

Dari pesan tersirat ayat tersebut, rasanya kita tidak menemukan kesalahan terkait peran serta perempuan dalam mencari tambahan penghasilan untuk meningkatkan taraf perekonomian masyarakat, khususnya keluarga. Dalam ayat yang lain Allah Swt menegaskan bahwa: "Barang siapa yang beriman dan beramal saleh dan Ia bekerja dengan berkwalitas tinggi (ihsan) baik laki-laki maupun perempuan maka kami akan memberikan kehidupan yang baik dan kami akan balas perbuatannya dengan yang lebih baik dari apa yang mereka kerjakan.." (QS. An-Nahl: 97). "Aku tidak akan menyia-nyiakan amal orang-orang yang beramal di antara kamu, baik laki-laki atau perempuan..." (QS. Ali Imron: 195). Dan janganlah kalian iri hati terhadap apa yang dikaruniakan Allah kepada sebagian kamu lebih banyak dari sebagian yang lain. (Karena) bagi laki-laki ada bahagian dari apa yang mereka usahakan, dan bagi wanita (pun) ada bahagian yang mereka usahakan (QS. An Nisa': 32). 
Ayat-ayat tersebut di atas dapat menjadi dasar bahwa pada hakekatnya kebaikan adalah melakukan hal-hal yang produktif dan bermanfaat bagi orang lain di lingkungannya. Kesempatan untuk berbuat kebaikan adalah sama antara laki-laki dengan perempuan, termasuk dalam hal mencari nafkah untuk meningkatkan kesejahteraan keluarga. Kebolehan seorang seorang istri mencari nafkah tambahan, misalnya melalui pemberdayaan koperasi, tentu harus tetap memperhatikan ketentuan yang telah disyariatkan. Artinya, selama kodrat sebagai ibu rumah tangga tidak dilanggar tentu boleh hukumnya.

\section{Koperasi Wanita}

Menurut istilah, yang di maksud dengan koperasi adalah perkumpulan yang di bentuk oleh anggota peserta yang berfungsi untuk memenuhi kebutuhan para anggotanya dengan harga yang relatif rendah dan bertujuan memajukan hidup bersama. ${ }^{23}$ Sejalan dengan pernyataan di atas, adalah Masjfuk Zuhdi, dalam ulasannya tentang koperasi menyatakan bahwa koperasi adalah suatu perkumpulan yang beranggotakan orang-orang atau badan hukum yang bekerja sama dengan penuh kesadaran untuk meningkatkan kesejahteraan anggota atas dasar suka rela secara kekeluargaan. ${ }^{24}$

Dalam narasi besar koperasi, ritme yang dimainkan di dalamnya adalah konsep kekeluargaan dengan misi mengapai kesejahteraan para anggotanya. Karena itu biasanya, koperasi yang didirikan memiliki dua macam usaha, yaitu: (a) Bersifat tunggal (single purpose), adalah koperasi yang menjalankan usahanya dalam satu bidang usaha, (b) Bersifat multi (multi purpose) usaha (lebih dari satu usaha atau serba usaha) dimana koperasi bergerak pada banyak bidang usaha yang melakukan pembelian dan dan penjualan. ${ }^{25}$ Apabila melihat klasifikasi koperasi tersebut, berarti jenis usaha yang di jalankan koperasi wanita "An-Nisa" sementara ini baru bergerak di satu bidang usaha, yaitu memberikan pinjaman/ kredit

\footnotetext{
${ }^{23}$ Hendi Suhendi, Fiqh muamalah. (Jakarta, Raja Grafindo Persada, 2007), h. 289.

${ }^{24}$ Ibid., h. 289. Lihat:, Masjfuk Zuhdi, Masail Fiqhiyyah, (Jakarta: Haji Masagung, 1988), h. 148.
}

kepada angota-anggotanya yang membutuhkan modal usaha.

Koperasi dapat disebut sebagai syirkah ta'awuniyah (perseroan tolong menolong). Sedang bentuk perseroan adalah sebuah model kerjasama yang disahkan secara syar'i karena dengan bersekutu akan tercipta kesatuan dan dengan adanya kesatuan akan tercipta kekuatan, dan hendaknya kekuatan ini digunakan untuk menegakkan kebenaran secara syar'i. Koperasi adalah wadah untuk saling melakukan tolong menolong di bidang ekonomi. Semangat tolong menolong dalam kebaikan dan ketakwaan, tersurat dalam al-Qur'an yaitu: “Dan tolong menolonglah kamu dalam (mengerjakan) kebaikan dan takwa dan jangan tolong menolong dalam berbuat dosa dan permusuhan" (QS. Al-Maidah: 2).

Implementasi tolong menolong dalam koperasi adalah tidak lain untuk mencapai kesejahteraan bersama diantara para anggota koperasi, dengan saling menutupi kebutuhan. Menutupi kebutuhan melalui tolong menolong dalam kebaikan adalah upaya mencapai ketakwaan yang sempurna. ${ }^{26}$ Logikanya, bila tolong menolong adalah salah perbuatan yang terpuji, sedangkan koperasi adalah organisasi yang melakukan tolong menolong, maka koperasi adalah organisasi yang terpuji. Jadi secara prinsip umum, dasar prinsip operasional koperasi adalah membantu kesejahteraan para anggotanya melalui prinsip tolong menolong dalam kebaikan (ta'awun alal birri) dan bersifat kolektif (berjamaah) dalam membangun kemandirian hidup. ${ }^{27}$

Koperasi wanita merupakan wadah yang paling tepat bagi kelompok perempuan pelaku usaha yang biasa disebut kelompok produktif dalam meningkatkan usahanya. ${ }^{28}$ Bahkan dalam

\footnotetext{
${ }^{26}$ Ibid., h. 295.

${ }^{27}$ http://www.bprsyariah.com/ (diakses Tanggal, 9 Oktober 2012)

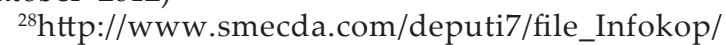
Vol.15_01/Koperasi_dan_Pemberdaya_peremp_3. pdf. jugadalam tulisan Huzaemah T. Yanggo yang menyatakan: tidak ada halangan bagi muslimah menjadi pengusaha, melakukan transaksi dan membelanjakan hartanya dan lain-lain, asal saja ia mempunyai kemampuan untuk itu dan dapat menjaga diri dalam berkarir sebagai pengusaha serta dapat menjalankan fungsinya sebagai istri terhadap suaminya, sebagai ibu terhadap anaknya, dan sebagai
} 
hadits Rasulullah SAW, bahwa kemandirian perempuan dalam berusaha selama itu adalah cara agar dia mampu mewujudkan kehidupan yang terhormat (bukan sebagai pemintaminta) bagi dirinya dan keluarganya, maka harta yang diperolehnya dianggap sunnah. Dukungan hadits ini sebagaimana terdapat dalam satu riwayat: "Suamimu dan anakmu adalah orang yang paling berhak mau beri sedekah" (HR. Bukhari dan Muslim). ${ }^{29}$

Makna yang memiliki kedekatan dengan konotasi "penguatan" adalah kata pemberdayaan, yaitu apabila terdapat sesuatu yang lemah atau dianggap belum mampu atau belum berdaya maka tindakan kongkritnya adalah dibuat mampu, diperkuat dan diberdayakan. Desain linguistik menyatakan bahwa pemberdayaan mempunyai makna harfiah membuat (seseorang) berdaya. Istilah lain untuk pemberdayaan adalah penguatan (empowerment). Pemberdayaan sejatinya adalah pemanusiaan, yaitu mendorong orang untuk menampilkan dan merasakan hak-hak asasinya. Didalam pemberdayaan terkandung unsur pengakuan dan penguatan posisi seseorang melalui penegasan terhadap hak dan kewajiban.

Pemberdayaan mengutamakan usaha sendiri dari orang yang diberdayakan untuk meraih keberdayannya. Oleh karena itu, bila merujuk dari substansi kata "pemberdayaan" itu sendiri, tentunya seseorang akan sangat jauh dari konotasi ketergantungan. ${ }^{30}$ Istilah pemberdayaan mengarah pada upaya mendidik, menumbuh kembangkan potensi yang ada, lewat sebuah tahapan proses yang sistematis menuju kemandirian dalam ekonomi dan pencapaian finansial. Jika pemberdayaan merupakan antagonis dari ketergantungan, maka ada beberapa hal yang perlu diperhatikan,

$\overline{\text { ratu dalam rumah tangganya. Lihat: Dadang S Anshori }}$ (Ed.), Membincangkan feminism; Refleksi Muslimah atas peran Sosial Kaum Wanita, (Bandung: Pustaka Hidayah, 1997), h. 84.

${ }^{29}$ Kitab Bukhari, Bab Berzakat kepada karib kerabat, jilid 4, h. 68. Kitab Bukhari, Bab: Berzakat pada suami dan anak yatim yang dipelihara, Jilid 4, h.71. Lihat: Abdul Halim Abu Syuqqah, Kebebasan Wanita. (Jakarta, Gema Insani Press, 1997), h. 430.

${ }^{30} \mathrm{http}: / /$ www.slideshare.net/imraanmuslim/babiipkkpemberdayaan-ekonomi (diakses Tanggal 24 Juli 2012) yaitu: (1) Proses primer yakni sebuah proses pemberdayaan yang menekankan kepada proses memberikan atau mengalihkan sebagian kekuasaan, kekuatan, atau kemampuan kepada masyarakat agar individu menjadi lebih berdaya; (2) Proses sekunder yakni menekankan pada proses menstimulasi, mendorong atau memotivasi individu agar mempunyai kemampuan untuk menentukan apa yang menjadi pilihan hidupnya melalui proses dialog. ${ }^{31}$

Islam sebagai agama yang memiliki konsep tegas sebagai rahmatan lil alamin, dan hal ini dapat dilihat dari tata aturan dan doktrin syariah islamiyah mencakup segala aspek kehidupan manusia. Diantara nadi kehidupan itu adalah di bidang ekonomi, dan hal yang substantif dari ekonomi adalah aspek perdagangan (tijarah). Islam mengarahkah kepada manusia agar dalam setiap transaksi harus menghindari praktekpraktek perdagangan yang dilakukan dengan cara yang salah (bil bathil...) yang notabene bertentangan dengan prinsip syariah, sehingga hukumnya adalah haram. Allah Swt berfirman: "Hai orang-orang yang beriman janganlah kamu saling memakan harta sesamamu dengan jalan yang bathil, kecuali dengan jalan perniagaan yang beralku dengan suka- sama suka diantara kamu" (QS. An-Nisa: 29).

Al-Qur'an menegaskan bahwa yang disebut dengan perdagangan adalah suatu proses dimana terjadinya pertukaran kepentingan untuk tujuan keuntungan tanpa adanya penekanan yang tidak dihalalkan atau adanya penipuan terhadap kelompok lain. Dengan kata lain, tidak boleh ada suap atau praktek riba dalam perdagangan. ${ }^{32}$ Selanjutnya, bila koperasi secara definitif adalah tersurat sebagaimana pernyataan yang dikemukakan oleh oleh Mohammad Hatta dalam bukunya "The Cooperative Movement in Indonesia" yaitu usaha bersama untuk memperbaiki nasib penghidupan ekonomi berdasarkan tolong menolong. ${ }^{33}$ Disamping itu, gerakan koperasi

\footnotetext{
${ }^{31} \mathrm{Ibid}$.

${ }^{32}$ Abdurrahman, Muamalah, (Jakarta: Raja Grafindo Persada, 1996), h. 6.

${ }^{33}$ Pachta W. Andjar, Hukum Koperasi Indonesia: Pemahaman, Regulasi, Pendidikan, dan Modal Usaha,
} 
adalah melambangkan harapan bagi kaum yang lemah ekonominya berdasakan self help dan tolong menolong di antara anggota-anggotanya yang melahirkan diantara mereka rasa percara pada diri sendiri dan persaudaraan. ${ }^{34}$

Merujuk padahal tersebut, adalah maklum jika pendirikan koperasi bertujuan untuk membantu sesama anggota, menciptakan kepedulian dalam menuju kesejahteraan bersama. Inilah yang dimaksud yang di maksud auto activitet golongan. Auto activitet golongan tersebut berdasarkan solidaritet, individualitet, auto activitet, self help dan jujur. ${ }^{35}$ Selanjutnya apabila kita gali lebih lanjut, maka akan terdapat beberapa nilai yang terkandung dari beragam definisi koperasi, yaitu: (a) Merupakan perkumpulan orang dan bukan semata perkumpulan modal; (b) Adanya kesamaan baik dalam tujuan, kepentingan maupun dalam kegiatan ekonomi; (c) Merupakan usaha yang berbentuk sosial tetapi tetap bermotif ekonomi; (d) Bukan semata untuk keuntungan badan koperasi itu sendiri, melainkan untuk kesejahteraan anggota; (e) Diurus dengan semangat kebersamaan dan gotong royong. ${ }^{36}$

Dasar yang paling utama ketika berdiri koperasi adalah dinyatakan oleh Casselman yaitu: Cooperation is an economic system with social contrast, yang berarti bahwa koperasi itu mengandung dua unsur, yaitu unsur ekonomi dan unsur sosial. ${ }^{37}$ Berangkat dari kedua aspek ini, salah satu peran besar perempuan dalam upaya meningkatkan taraf hidup masyarakat, yaitu dengan memberikan pembiayaan yang bersifat (pinjaman lunak) pada usaha mikro kecil dan menengah (UMKM) yaitu dengan sistem pinjaman koperasi dengan menggunakan sistem qord al-hasan (pinjaman lunak). ${ }^{38}$ Sedang

(Jakarta: Prenada Media, 2007.), h. 19

${ }^{34}$ Ibid.

${ }^{35}$ Ibid. h. 19.

${ }^{36}$ Ibid. h. 20-21. Lihat: Hartini, Rahayu. Aspek Hukum Bisnis, (Malang: UMM Press, 2007), h. 100-102.

${ }^{37}$ Ibid. h. 21. Lihat: Hadhikusuma, R.T. Sutantya, Rahardja. Hukum Kopearasi Indonesia.(Jakarta, Raja Grafindo Persada, 2005).h. 40-41. Pada Pasal (4) UU No. 25 Tahun 1992, telah diuraikan unsur sosial koperasi diatur, Lihat: Hadhikusuma, R.T. Sutantya, Rahardja. Hukum Kopearasi Indonesia.(Jakarta, Raja Grafindo Persada, 2005).h. 40-41.

${ }^{38} \mathrm{Al}$-qur'an menamakan sistem al-Qard dengan istilah al-qard al-hasan, sebagaimana tersurat dalam QS. Al Hadid: 11. Al-qard al-hasan yang merupakan makna sistem qord al-hasan sendiri adalah pemberian harta kepada orang lain yang dapat ditagih atau diminta kembali, dengan kata lain meminjamkan tanpa mengharapkan imbalan. Produk al-Qard al-hasan ini digunakan untuk membantu usaha kecil, keperluan kecil, dan keperluan sosial. ${ }^{39}$

Disisi lain sistem $A l$ Qard sendiri merupakan ruang lingkup fiqih muamalah ${ }^{40}$ yang merupakan salah satu usaha dalam pemerataan berusaha dan kesempatan kerja sebagai perwujudan dari program pemberdayaan ekonomi masyarakat. ${ }^{41}$ Tentu secara konsep, perspektif pemberdayaan usaha kecil menengah (UMKM) dengan segala karakteristiknya dituntut untuk menangkap peluang dalam situasi ekonomi yang sulit yaitu dengan konteks fleksibilitas yang tinggi dan disertai dengan dukungan manajemen yang memadai dalam menghasilkan produk

pinjaman bagi mereka yang amat membutuhkanagar terhindar dari kesusahan-, bersifat bantuan dan berdasarkan tolong menolong (at-ta'awun). Lihat: al-Sihhat al-jundi. Muhammad"al-Qord kadzatu li-altamwil fii as-syariah Islamiyah" (Kairo, al-Ma'had alalamy llfikri al-Islami. 1996).h. 172-173.

${ }^{39}$ Dana al-Qard di peroleh dari dana zakat, infaq dan shadaqah serta dana lain yang halal dan tidak mengikat. Lihat: Sulhan.M. (et.al). Manajemen Bank Konvensional dan Syariah.(Malang, UIN Malang Press, 2008,)h. 138-139. Dalam hal ini fungsi social lebih di utamakan Konsep Koperasi Syariah mengharuskan memberikan pelayanan sosial baik kepada anggota yang membutuhkannya maupun kepada masyarakat dhu'afa.tentang koperasi yang bersifat syar'I, Lihat: http://www.bprsyariah.com/ (diakses tgl.9 oktober 2012)

${ }^{40}$ Dimana fiqih muamalah adalah hukum-hukum syarak yang bersifat praktis amaliah yang di peroleh dari dalil-dalil terperinci yang mengatur hubungan keperdataan seseorang dengan orang lain dalam hal persoalan ekonomi, diantaranya: dagang, simpan pinjam-meminjam,sewa-menyewa, kerjasama dagang simpanan barang atau uang, penemuan, utang piutang, pungutan, dan lain-lain. Lihat: Ali, Zainuddin. Hukum Ekonomi Syariah, (Jakarta, Sinar Grafika, 2008,) h. 118119.

${ }^{41} \mathrm{Hal}$ ini bisa di lihat dalam tiga sasaran program pemberdayaan ekonomi masyarakat yaitu: Pertama: memungkinkan terciptanya suasana atau iklim potensi masyarakat berkembang (enabling), Kedua: memperkuat potensi atau sumberdaya yang dimiliki oleh masyarakat (Empowering), Ketiga: proses pemberdayaan harus melindungi dan mencegah (Protecting) yang lemah bertambah lemah di sebabkan oleh ketidakberdayaan dalam menghadapi yang kuat. Lihat dalam tulisan Umrotul Hasanah M.Si, 2008. Pembangunan Ekonomi BerprespektifGender"dalam Buku: Sumbulah, Umi. Spektrum Gender;kilasan inklusi gender di perguruan tinggi. (Malang, UIN Press. 2008).h.130. 
dan jasa. ${ }^{42}$

Dalam konteks pemberdayaan ekonomi masyarakat, tentu kita membutuhkan kesimbangan untuk mengoptimalisasikan kekuatan terhadap seluruh potensi (termasuk pemberdayaan perempuan) dalam konteks penguatan interaksi-relasi (interaction-relationship) baik antara rakyat dengan negara, maupun rakyat dengan rakyat. Pada kedua pola hubungan interaktif tersebut, rakyat ditempatkan sebagai bagian integral dalam komunitas negara yang memiliki kekuatan bargaining position dan menjadi masyarakat sipil yang memiliki kecerdasan, analisis kritis yang tajam serta mampu berinteraksi di lingkungannya secara demokratis dan berkeadaban..$^{43}$ Dari sini pemaknaannya dapat di cerna, bahwa keberadaan koperasi merupakan wadah orangorang atau badan hukum yang mempunyai kepentingan bersama dalam meningkatkan kesejahteraannya.

\footnotetext{
${ }^{42}$ Ibid, h. 130.

${ }^{43} \mathrm{Ibid}$, h. 55.
}

\section{Daftar Pustaka}

Abu Syuqqah, Abdul Halim, Kebebasan Wanita, Jakarta: Gema Insani Press, 1997

Ali, Zainuddin. Hukum Ekonomi Syariah, Jakarta: Sinar Grafika, 2008

Al-Sihhat al-jundi, Muhammad, Al-Qord Kadzatu li-al-Tamwil fii as-Syariah Islamiyah," Kairo: al-Ma'had al-alamy llfikri al-Islami, 1996

Andjar, Pachta W., Hukum Koperasi Indonesia:Pemahaman, Regulasi,Pendidikan, dan Modal Usaha, Jakarta: Prenada Media Group, 2007

Anshori, dadang S (Ed.), Membincangkan feminism; Refleksi Muslimah atas peran Sosial Kaum Wanita, Bandung: Pustaka Hidayah,1997

Doi, Abdurrahman I, Muamalah. Jakarta: Raja Grafindo persada, 1996.

Hadhikusuma, R.T. Sutantya, Rahardja. Hukum Koperasi Indonesia.Jakarta, Raja Grafindo Persada. 2005.

Hartini, Rahayu, Aspek Hukum Bisnis, Malang: UMM Press, 2007

Irianto, Sulistyowati (ed.). PerempuanEhukum; Menuju Hukum yang Berspektif Kesetaraan

\section{Kesimpulan}

Peranankaumperempuan dalammeningkatkan kesejahteraan di tengah masyarakat ekonomi sesungguhnya memiliki konotasi produktif dan inovatif. Koperasi wanita (Kopwan) yang diberi nama "An-Nisa", adalah bermula dari sebuah ide sederhana yaitu ingin hidup lebih layak dan sejahtera secara bersama-sama. Berawal dari kemauan yang kuat, kaum perempuan mempunyai motivasi tinggi guna mencapai cita-cita tersebut. Dalam bahasa sederhana, "peran aktif" pada konteks perempuan adalah sebuah pemberdayaan potensi secara optimal menuju produktifitas, sehingga mereka mampu mencapai kesejahteraan ekonomi melalui kegiatan koperasi. Partisipasi perempuan melalui koperasi, terbukti telah membantu perekonomian keluarga, disamping dari aspek sosial dapat meminimalisir stigma masyarakat bahwa perempuan adalah the marginal person alias "hanya" konco wingking, yang "hanya" menjadi obyek pelengkap dalam kehidupan.

dan Keadilan,Jakarta: Yayasan Obor Indonesia, 2008.

Jurnal KARSA, Vol. 19. No.2. Tahun 2011.

Sulhan.M. (et.al), Manajemen Bank Konvensional dan Syariah, Malang: UIN Malang Press, 2008

Sumbulah, Umi, Spektrum Gender; kilasan inklusi gender di perguruan tinggi, Malang: UIN Press, 2008.

Web Site

http://www.smecda.com/deputi7/file_Infokop/ VOL15_01/Koperasi_dan_Pemberdaya_ Peremp_3.pdf (diakses tanggal $1 \mathrm{Mei}$ 2012)

http://jombang.nu.or.id/islam-danpemberdayaan-perempuan/ (diakses tanggal14 Oktober 2012)

http://www.bprsyariah.com/ (diakses tanggal.9 oktober 2012)

http://eljannahraheem.blogspot.com/2008/12/ peranan-wanita-dalam-masyarakat.html (diakses tanggal 19 oktober 2012)

http://www.suara-islam.com/read5704-IslamMemuliakan-Perempuan.html (diakses tanggal 22 oktober 2012) 